\title{
Financial impact of using EUR call options to hedge accounts receivables
}

\author{
Dr. Kenneth B. McEwan \\ Grace College, School of Business \\ Winona Lake Indiana, USA
}

\begin{abstract}
Keywords
Exchange rates, payables, EUR/USD, call options, hedging
\end{abstract}

\begin{abstract}
International business has grown rapidly in recent years as companies seek to take advantage of expanding supply chain opportunities. As companies enter into contracts to take advantage of engineering, production, and cost reduction capabilities of the global supply chain, they may be creating a foreign currency exchange rate risk. The quantitative study examined the 60-day EUR/USD exchange rate fluctuation and the use of currency call options to hedge the risk associated with EUR/USD currency fluctuations. The researcher analyzed 13 years of historical EUR/USD currency data and 10 years of actual EUR call options premiums for this research paper. The researcher concluded that the variability of the EUR/USD over 60-days does pose financial risk to a company. The study also found that using currency call options to hedge this 60-day exchange rate risk resulted in an overall transactional financial loss as compared to no hedging. However, research studies have shown that the use of hedging instruments to smooth financial results may result in lower overall financing costs which could offset the hedging transactional costs. This study did not address the benefits of the use of hedging to smooth financial results or obtain other related financial benefits. The researcher recommends that a firm should recognize the exchange rate risks it may be establishing within 60-day EUR or USD payable contracts and develop an appropriate hedging strategy.
\end{abstract}

\subsection{Introduction}

To capture opportunities in the supply chain, many companies have expanded into foreign markets to develop foreign suppliers. These contractual arrangements may have required companies to issue an order in a foreign currency upon which the companies faced a foreign exchange currency risk. In other words, the companies face circumstances where the value of an order to a supplier may have changed from the time the order was issued until payment. The problem is that companies who have contracted with a foreign supplier are likely to face foreign currency exchange risks which can result in significant financial impacts (Bloom and Cenker, 2008; Edens, 2010; Moosa, 2004; Spreckelsen et al., 2014; Treanor et al., 2014; Veestraeten, 2013). Broll and Wong (2015) stated that hedging currency risk exposure is essential for multinational companies. This paper studies the top currency pair used in international trading, the United States Dollar (USD) and the European Union Euro (EUR), to determine if a company should consider using currency options to hedge an exchange rate risk (Costantini et al., 2016; Galeshchuk and Mukherjee, 2017). Currencies are listed in pairs with the first currency listed standing for one unit of that currency, the second currency is the amount of that currency required to purchase one unit of the first currency. If the EUR/USD exchange rate is listed as 1.3005, then it costs 1.3005 USD to purchase one EUR.

The researcher studied the use of currency call options to hedge the risk of EUR/USD currency fluctuations. Call options give the firm the right but not the obligation to purchase currency for a fixed price during a specific period of time. A firm in the United States could purchase an EUR call option to hedge an account payable. If the EUR strengthened, the firm could exercise the option and obtain the EUR for the fixed price. For example, from January 12, 2011, to March 14, 2011, the EUR appreciated by $6.5 \%$ against the USD, which would have increased a 1,000,000 EUR payable from $\$ 1,313,700$ to $\$ 1,399,000$, a $\$ 85,300$ increase. A loss of $\$ 85,300$ in the span of 60 days could negate a profitable transaction. An importer could have hedged this currency risk with a 60-day EUR call option costing approximately $\$ 34,300$. 
For this study, historical data were used when analyzing the premium for call options to determine if the cost of purchasing these options could be less than the benefits of the hedge (Spreckelsen et al., 2014; Stulz, 2013). In other words, actual historical pricing data were used for the call option premiums to determine if the net benefit was favorable. The advantages of using currency options to hedge 60-day accounts payable must be considered against the actual premium of the option (Moosa, 2004). Historical option prices for the EUR/USD 60-day call options from 2007 to 2016 were used, along with the corresponding historical EUR/USD currency data. This 10-year timeframe contained both recessionary and expansionary economic conditions, which increases the reliability of the study.

Figure 1 shows the premium for call options that could have been purchased to hedge a 60-day accounts payable liability. The premium escalated during the 2007-2009 recession which was also a period of high levels of economic instability. This increasing premium during a period of economic instability is consistent with theoretical option pricing formula, including the often used Black-Scholes option pricing model (Charvin et al., 2014; Manzur et al., 2010).

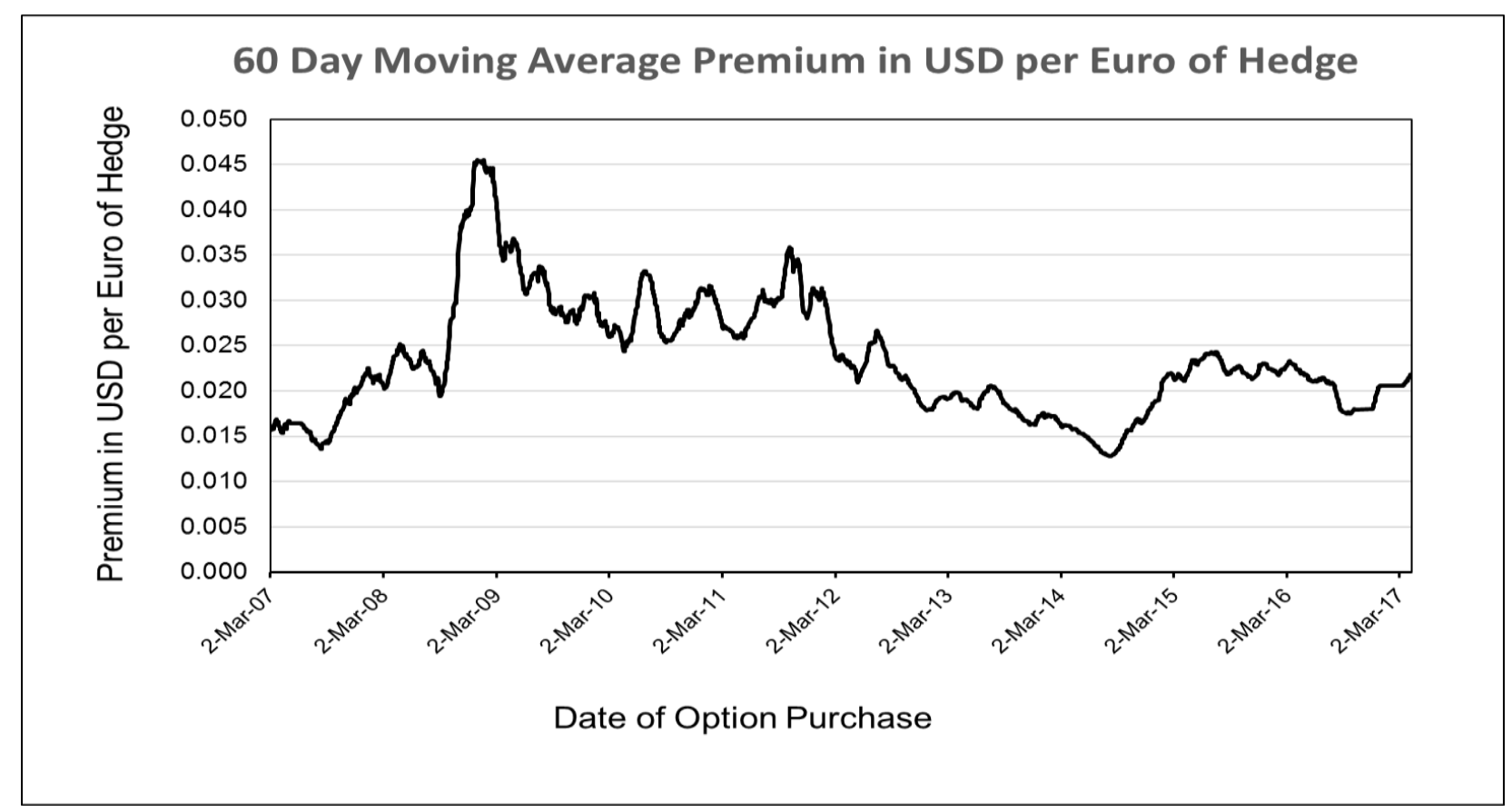

Figure 1. Line plot of the 60-day moving average premium of a EUR call option from March 2007 to March 2017.

\subsection{Literature review}

Companies are increasingly looking internationally to expand their markets, obtain critical resources, develop new capabilities, and reduce costs. Firms which have expanded into the international marketplace are likely to face the risks of currency fluctuations and as such they may need to consider how to manage these risks. Active risk management and the use of derivatives have been shown to increase valuation and improve financial results.

The use of options to manage risks and the pricing of these options have been studied, however, the majority of the studies use theoretical option prices, not historical option prices. The author used actual option prices as incurred on the Chicago Mercantile Exchange to avoid the errors found in traditional option price calculation. The literature review supports the increasing use of global suppliers, the exchange rate risk associated with these global supplies, and the use of hedging instruments to address these risks.

Companies are increasingly establishing strategic relations with outside suppliers to deliver improvements in costs, process efficiencies, innovation, and customer services. This increase in outside supplier contracts has involved manufacturing activities and such traditional in-house activities as 
engineering, research and development, administration, and management functions. A firm using global outsourcing can focus on core competencies while seeking low-cost, global sources with the appropriate quality and delivery capabilities. Global outsourcing allows the firm to minimize fixed costs and maintain a high degree of asset utilization (Doval, 2016).

The FOREX market is large and liquid with currencies being traded on a constant basis (Baranga, 2016; Cevik et al., 2017; Pilbeam and Langeland, 2015). The valuation of currencies involves a complex set of factors, including economic conditions, interest rates, consumer sentiment, the political environment, taxes, and global trading conditions (Engel, 2016; Kumar and Joshi, 2014). Risk managers consider currency exchange rate fluctuations as a significant risk factor which may reduce firm value through the impact on cash flows (Parlapiano et al., 2017). The buying and selling of foreign currency forwards, futures, and/or options are used to cover short exposures such as payables, or long exposure such as receivables (Moosa, 2004). Companies who have successfully addressed the foreign currency risks have more predictable financial results and once the hedging instruments are in-place, these companies are able to focus their efforts on more value-added activities. By using hedging instruments, companies can narrow the distribution of probable cash flow which lowers the likelihood of financial distress (Edens, 2010; Magee, 2013).

An international company's supply chain may be impacted by currency rate fluctuations according to Mishler (2017). The impact of the currency rate changes could negatively affect the importer, the supplier, the distribution channel, or even the end user. Multinational companies, especially small and medium sized firms can be assisted by a comprehensive exchange rate management strategy. An effective currency risk management strategy is executed by both the financial and purchasing organizations. The strategy identifies the risk exposure and determines when and how to mitigate the risks. The use of foreign currency options is a common hedging vehicle (Mishler, 2017).

Managing currency risks is an important part of managing a global corporation (Broll and Wong, 2015). The fluctuations in global currencies are a major concern for multinational companies as profitability can be significantly impacted by currency variations. Trading of hedging instruments between the home currency and the foreign currency helps a multination corporation manage its risk. Less developed countries and emerging markets may not even have their currencies traded in the futures or forwards markets. For these countries, an organization may be able to use a hedging instrument for a traded currency which has movements that are similar to the emerging market currency.

Perez-Gonzalez and Yun (2013) stated that the value of risk management and specifically hedging is a highly debated issue in corporate finance. Theoretical studies have shown that in a frictionless setting, hedging is not relevant for firm value, however, risk management and hedging in particular have experienced rapid growth. The authors found evidence that the use of derivatives to manage risk leads to higher firm value and increased investments. The use of hedging instruments such as forwards and futures enhance the reputation of an organization which may result in more favorable terms for other types of financial transactions (Campello et al., 2011). Hedging works as a mechanism that limits the risk of negative cash flows which helps firms get access to external funding.

Firms with high-risk foreign contracts benefit from lower financing costs when these high-risk contracts are appropriately hedged. When companies have future payments, costs, or asset purchases planned in a foreign currency then the companies are facing currency risk. This currency risk can have a substantial impact profitability and cash flow for the multinational firm (Frishberg and Gobble, 2013). Companies can be exposed to adverse changes in interest rates, commodity prices, and foreign currency exchange rates therefore hedging strategies should be part of the top-level strategic plan (McMillan and Overall, 2017). Smaller companies can benefit from the cost savings and increased flexibilities with outsourcing however, these companies often overlook the risks associated with exchange rate fluctuations (Gylling et al., 2015).

Low and Zhang (2005) studied foreign currency options for the GBP, the EUR, the JPY and the $\mathrm{CHF}$ and found that buyers in the options market pay a premium to the sellers to compensate the sellers for bearing the volatility risk. The Low and Zhang (2005) study confirmed that market volatility impacts EUR/USD option pricing which is demonstrated in the increase in option pricing during the global 
financial crisis. The study does not address the net benefit, if any, from using options as a hedging instrument during times of high or normal volatility.

This quantitative study examined the historical fluctuation of the EUR/USD currency pair. The USD and the EUR make up 63\% and 20\% respectively of the 2017 global foreign exchange reserves (Issing, 2018). As a global means of payment in 2017, the USD makes up $40 \%$ while the EUR accounts for $36 \%$ (Issing, 2018). The European Union accounted for 35\% of global foreign direct investment (FDI) inward flow and $40 \%$ of global FDI outward flow in 2014, while the U.S. accounted for $21 \%$ of global inward FDI flow and 24\% of global outward FDI flow in 2014 (Witkowska, 2017). The USD and the EUR have a dominant role as a global means of payment, as reserve currencies, and in FDI flow.

\subsection{Research methodology}

The researcher statistically analyzed the EUR/USD currency fluctuations and option price fluctuations using statistical analysis software and developed mathematical models to analyze the net benefit of using call options to hedge the EUR/USD currency fluctuations (Ljung et al., 2014). The options modeled were approximately 60-day call options which represent a 60-day period between transaction initiation and transaction completion. For example, a call option would be useful for a company which has outsourced a product or service and is expecting to pay in foreign currency. By using data from 2007 to 2016, the study addressed the use of the EUR/USD currency options when the global economy experienced both extreme volatility and relative calm. The author used approximately 60-day options to address the relative shorter-term foreign currency risks that companies may experience in accounts payable. Kroes and Manikas (2014) found that average accounts payable days was approximately 60 days.

The EUR/USD currency option prices used in this study are actual prices from January 1, 2007, to December 31, 2016. The option prices include high volatility economic conditions which occurred during the global 2008 recession and the economic recovery. Also, included were option prices when economic conditions were relatively stable. The option prices were obtained from the Chicago Mercantile Exchange (CME Group) which each day of trading data being downloaded and converted into an Excel file. The result was 2,510 call options with an average duration of 74 days. Currency options handled by the CME Group have standard once per month closing dates and the author ensured the 60-day accounts payable currency risk would be adequately hedged in its entirety. The EUR/USD exchange rate information was downloaded to Excel from the US Federal Reserve using the FRED reporting system. The US Federal Reserve releases daily rates of exchange for major currencies against the USD on a weekly basis. The statistical analyzes in this study, includes common statistical measures such as range, skewness, standard deviation, coefficient of variation, correlation and other measures (Weltman and Eakin, 2018).

\subsection{Findings/results}

This research on the EUR/USD exchange rate risk shows agreement with (Bessler et al., 2019; Crowder, 2014; Frishberg and Gobble, 2013; Mishler, 2017) that foreign currency exchange rate risk is significant, and that hedging should be considered for this risk even considering a relatively short timeframe such as 60-days. The statistical analysis of the dataset from January 2, 2007, to December 31, 2019, shows that the average 60-day change in the EUR/USD exchange rate was minus .13\%. During this timeframe, on average, the EUR was depreciating. The EUR/USD currency exchange rate was downloaded from the Federal Reserve database system which is a publicly available source, and the research time frame includes a global recession, recovery, and steady growth. The researcher used Excel and Minitab for the analysis with no special coding or software changes. The statistical analysis indicated that skewness was -.39 and kurtosis was .64 which indicate that the data generally fits a normal curve (Aljarrah et al., 2019). A visual review of the data also indicates that a normal curve fits the data reasonably well (Saundage et al., 2016). The standard deviation of the 60 -day change was 3.83\% with a maximum depreciation of the EUR versus the USD of $15 \%$ and a maximum appreciation of $12 \%$. A firm could expect that $32 \%$ of the time the variance of 60 -day accounts payable would be higher than $3.83 \%$. In the worst-case scenario, during the study period, a firm could have incurred an increase of $12 \%$ in expense for a payable liability over a 60-day period. Table 2 shows the descriptive statistics for the EUR/USD fluctuations over a 60-day time frame. 


\begin{tabular}{cc}
\hline Statistic & Values \\
\hline Average EUR/USD exchange rate & 1.2737 \\
$\mathrm{~N}$ & 3,204 \\
Mean & $-.13 \%$ \\
Minimum & $-15 \%$ \\
Maximum & $+12 \%$ \\
\hline
\end{tabular}

Table 2 Descriptive Statistics for the EUR/USD Change

Over an Approximate 60-Day Time Frame

As shown in Figure 3, the percentage change over a 60-day timeframe was fairly aligned with a normal distribution. Using the data from the 13-year time period from 2007 to 2019, a company could be $95 \%$ confident that the 60 -day currency exchange rate would move between $-8.2 \%$ to $+8.2 \%$.

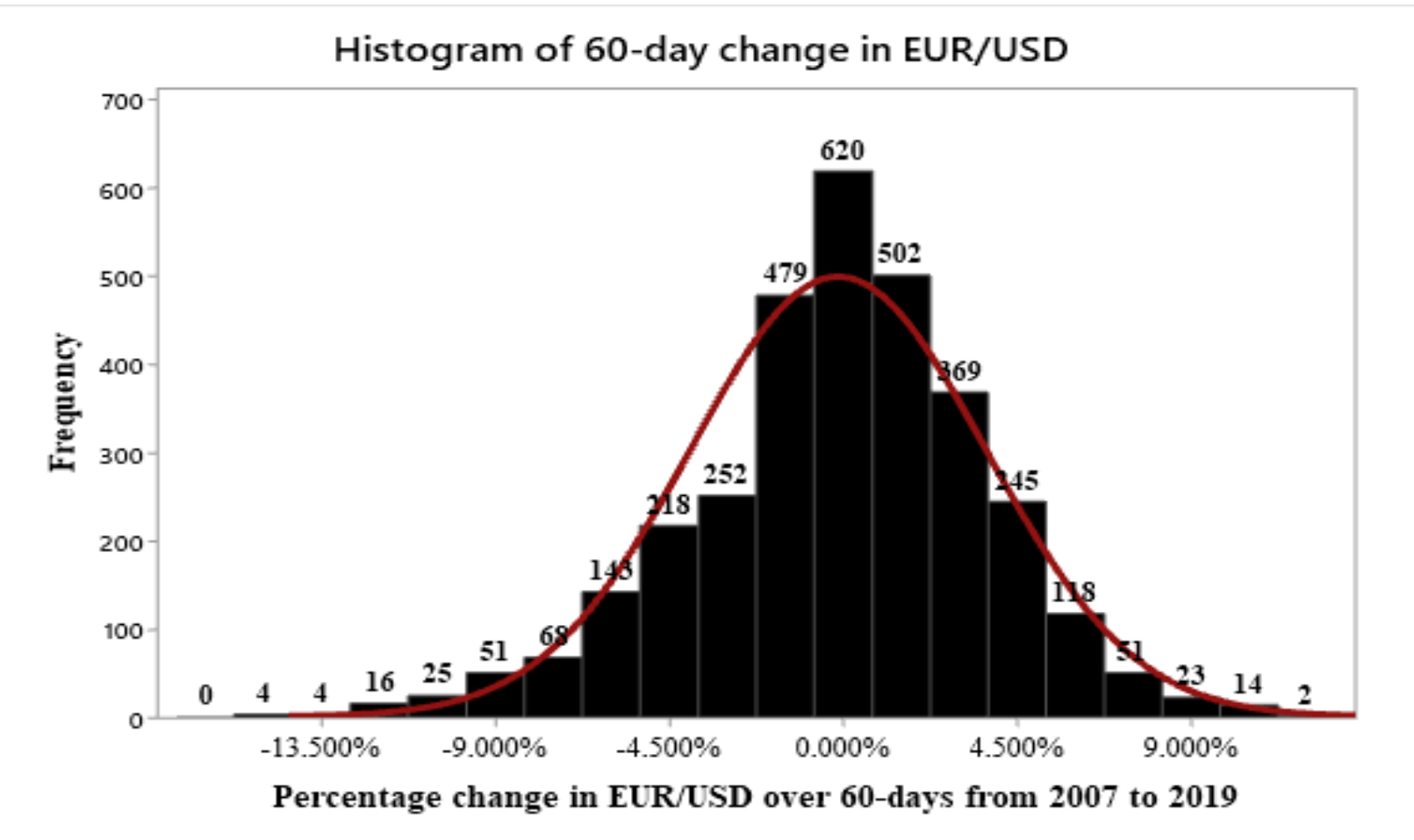

Figure 2. Histogram of the 60-day percentage change in the

EUR/USD exchange rate overlaid with a normal curve.

The results of the analysis of using EUR currency call options to hedge 60-day payables is consistent with previous option price research studies such as Charvin (2014) and Vanderlinden (2014). The study shows that hedging every 60-day accounts payable transaction with a currency call option, during the study period, 2007 to 2016, will result in a negative net transactional benefit to a company. Currency call options give the firm the right but not the obligation to obtain EUR for a set price, called the strike price, on a specific date. For this risk protection the firm pays a fee for the option which is called the premium. The analysis uses 2,510 daily records of EUR/USD call option data spanning January 1, 2007, to December 31, 2016. US holidays and weekends are not included when the option market is closed. The daily EUR/USD call options were selected for the analysis using two criteria: the daily call option with the 
EUR/USD strike price closest to the EUR/USD spot; and the EUR/USD call option with expiration closest to 60 days but not under in most cases. This methodology of selecting the strike price and time frame for the option hedging instrument was used by Manzur et al. (2010), while VanderLinden (2014) used a similar methodology for selecting the options for analysis, setting strike equal to $95 \%$ of the current spot price.

For this study, the first opportunity to purchase an option to hedge an accounts payable transaction occurred on January 2, 2007, meaning that the 60-day accounts payable would mature on March 2, 2007. The last opportunity to purchase a call option would be November 2, 2016, with the accounts payable maturing on December 30, 2016. The total number of opportunities to purchase and exercise the EUR/USD call options was 2,469. Assuming that a EUR/USD call option for 125,000 EUR was purchased for each of the 2,469 possible transactions, the total premium would have been 7,261,563 USD to hedge a total of 308,625,000 EUR accounts payable. The average cost to hedge 125,000 EUR was 2,931 USD. Using the average exchange rate of 1.3122 for the study period, the USD value of the 125,000 EUR hedge would have been on average 164,025 USD which calculates to premium costs of approximately $1.79 \%(2,931$ USD/164,025 USD).

The study shows that approximately, $49 \%$ of the call options would be exercised. The overall loss on this level of hedging would be 1,613,513 USD. The total value hedged would have been 308,625,000 EUR or using the average price of the EUR of 1.3122 USD, the value of the hedge would have been 405,022,488 USD. The overall loss for this hedging policy would have been .4\% $(1,613,513 / 405,022,488)$. During the study period an unhedged position would have netted 1,218,963 USD or .3\% due to the overall movement of the EUR/USD during this time frame. Although the policy of hedging every EUR payable over this time frame would have resulted in a negative net transactional cost, the firm would have avoided 215 instances where the non-hedged position would have a currency exchange loss of greater the $5 \%$. The company would have to consider the ramifications of a greater that $5 \%$ currency loss on $8.7 \%$ of its EUR payables transactions. Currency hedging instruments allow a company to better manage risk and predict cash flow and earnings. Studies have shown that a firm with a well-constructed currency management plan will likely improve its financial predictability and banking relations (Edens, 2010; Pérez-González and Yun, 2013; Wong, 2017).

For treasury, finance, and purchasing executives and managers this study shows that the EUR/USD does fluctuate over a 60-day time frame with enough volatility to justify the consideration of a hedging strategy. The study also shows that currency options can be used to hedge the currency risk however, the cost of the hedge is greater than the net benefit. During the study time frame from 2007 to 2019, a firm which did no hedging would have experienced a $0.3 \%$ currency gain on a 60 -day accounts payable. A firm using a EUR option to hedge every payable transaction would have experience a $0.4 \%$ overall loss on currency movement due to the premium (cost) of the hedging instrument which agrees with the findings of Bayas (2018). However, a firm using options to hedge the EUR/USD currency risk could have benefited from more consistent financial reporting and cash flow (Edens, 2010).

When conducting business on an international basis and transacting in foreign currency the organization is taking a risk on foreign currency fluctuations. The analysis in this paper indicates that even the highest traded currency pair, the EUR/USD, has enough volatility to warrant consideration of a hedging strategy. A firm's treasurer, finance and purchasing leadership should consider the variability of the EUR/USD exchange rate when planning the business. The use of options to hedge currency risks protects the financial assets of the organization and may improve stakeholder well-being by smoothing cash flow and income which allow the organization to better plan its activities. As Proverbs 14:15 says "the simple believe anything, but the prudent give thought to their steps" (NIV). Treasurers, financial and purchasing executives as good stewards should carefully consider the steps, they take in addressing exchange rate risks contained in the firm's contracts even over the relatively short time frame such as experienced with payables.

\subsection{Discussions and conclusions}

The results of this study indicate that a firm should recognize the exchange rate risks it may be establishing within 60-day EUR or USD payables contracts. The EUR/USD exchange rate, over the study time frame, 2007 to 2019, had a standard deviation of 3.83\% with a maximum depreciation of the EUR 
versus the USD of $15 \%$ and a maximum appreciation of $12 \%$. In the worst-case scenario a firm could have incurred an increase of $12 \%$ in expense for a EUR payable liability over a 60 -day period. Treasurers, finance and purchasing executives should make employees, especially buyers, aware that currency volatility could impact the firm's financial results and that risk mitigation actions such as currency hedging should be considered (Bessler et al., 2019). Both the USD and the EUR are considered as reliable, stable currencies yet the EUR/USD exchange rate has demonstrated significant volatility.

As a hedging strategy, treasurers and finance professionals may make use of currency options. Currency options have a great deal of flexibility because the buyer of an option has the right, but not the obligation, to exercise the option (VanderLinden, 2014). The buyer of an option only exercises the option when there is financial benefit. Option contracts may be used to protect the firm from downside risks however, this protection does have a cost through the premium that is charged for the purchase of an option. Treasurers and financial professionals may also consider other options for hedging EUR/USD currency risks such as futures, forwards, advanced payments, deposits and selling product into the other currency regime.

In dichotomy to the research studies supporting hedging foreign currency risks, firms may choose not to hedge foreign exchange rate risks. The use of hedging instruments adds costs and possibly staff who have the expertise to develop and execute the hedging plan. The mere mentioning of currency risks and the use of derivatives may increase stockholder awareness of these risks which could result in decreased stock price (Jankensgård, Hoffmann, \& Rahmat, 2014). Investors have been known to strongly focus on the profitability of core operations and the disclosure of foreign exchange risk which clutters the income statement and balance sheet may make investors assume management is taking on more risk instead of reducing risk. As this research study shows, the net impact of the EUR/USD movement was a slight improvement in the financial results, which indicates that over the longer-term EUR/USD exchange rate variations may have little impact on the financial results.

When negotiating contracts which require foreign currency payments, supply chain management professionals must recognize the volatility of the currency exchange rate and notify and work with their finance counterparts to develop a hedging strategy. Then the financial implications of the hedging strategy should be included as part of the supplier selection process. The analysis indicates that the cost of hedging a foreign currency risk should be considered when comparing domestic versus foreign suppliers. This study indicates that the premium for purchasing EUR call options is approximately $1.8 \%$ which could be incorporated into a firm's supplier evaluation process. The USD and the EUR are highly traded currencies and as such the premium for purchasing call options is likely lower than for other currencies. Therefore, supply chain professionals may need to research the costs of hedging other currencies when analyzing and negotiating supply contracts.

\subsection{Limitations and direction for future research}

This study was bounded by the fluctuations and characteristics of the EUR/USD and the associated call options. The author bounded the study by using EUR/USD options with the strike that is closest to the spot price when the option was purchased (Manzur et al., 2010). For example, on December 30, 2016, there were 28 different call options available for trading with various strike prices, the author chose the call option with the strike price closes to the current spot price. The author limited the study in this manner to keep the study a reasonable size and to establish a workable methodology for firms to follow to hedge payables. The author chooses to limit the quantitative analysis to the time frame of 2007 through 2019. This time frame included both recessionary and expansion economic conditions but did not include the complete history of the EUR/USD currency trading or option trading.

The research and findings in this study add to the current literature regarding the exchange rate risks associated with 60-day foreign currency payables and the use of options to hedge shorter-term exchange rate risks. Research studies by Charvin et al. (2014), Chen et al. (2019), Ardoin and Rodriguez (2017), and Spreckelsen et al. (2014) identified research gaps in the relatively short-term frame of previous exchange rate studies and the use of theoretical option prices instead of market-based option prices. The research in this study covers a relatively long-time frame, 13 years of EUR/USD exchange rate data, and uses market price data for calculating the financial benefit of the use of options for hedging exchange rate risk. The following are recommendations for further study. 
The focus of this study has been on the highest traded currency pair, the EUR/USD. Additional research into the movement of other currency pairs will add to the existing research. Research into other highly traded currency pairs such as the USD and the Chinese Yuan (CNY), the USD and the Great British Pound (GBP) and the CNY and the EUR would expand the literature on exchange rate modeling.

The criteria of the currency option selection could be varied. In this study the author choose the option with the strike price closest to the current spot price which impacts the cost of the option. An option sectional criterion that accepts more risk but searches for options with lower premiums may provide a lower cost hedging methodology. For example, a hedger could choose an option that limits the risk to $5 \%$ which would likely reduce the cost of that option.

\section{References}

Aljarrah, M.A., Famoye, F., Lee, C., (2019). A new generalized normal distribution: Properties and applications. Commun. Stat. - Theory Methods 48, 4474-4491. https://doi.org/10.1080/03610926.2018.1483509

Ardoin, E., Rodriguez, A., (2017). Negative interest rates and a possible rift in interest rate parity and arbitrage. Int. J. Bus. Account. Finance 11, 48-62.

Baranga, L.P., (2016). Study on the new financial products traded on the FOREX market. Bull. Transilv. Univ. Brasov Ser. V Econ. Sci. 9, 179-188.

Bayas, A., (2018). Currency Risk Management: Predicting the EUR/USD Exchange Rate. Major Qualif. Proj. Years.

Bessler, W., Conlon, T., Huan, X., (2019). Does corporate hedging enhance shareholder value? A meta-analysis. Int. Rev. Financ. Anal. 61, 222-232. https://doi.org/10.1016/j.irfa.2018.11.010

Bloom, R., Cenker, W.J., (2008). Derivatives and hedging: Accounting vs. taxation. J. Account. 206, 54-58.

Broll, U., Wong, K., (2015). Trade and cross hedging exchange rate risk. Int. Econ. Econ. Policy 12, 509-520. https://doi.org/10.1007/s10368-014-0291-x

Buen Sin Low, Shaojun Zhang, (2005). The volatility risk premium embedded in currency options. J. Financ. Quant. Anal. 40, 803-832.

Campello, M., Lin, C., Ma, Y., Zou, H., (2011). The real and financial implications of corporate hedging. J. Finance 66, 1615-1647. https://doi.org/10.1111/j.1540-6261.2011.01683.x

Chen, S.-N., Hsu, P.-P., \& Liang, K.-Y. (2019). Option pricing and hedging in different cyclical structures: A twodimensional Markov-modulated model. The European Journal of Finance, 25(8), 762-779. https://doi.org/10.1080/1351847X.2018.1538895

Cevik, S., Harris, R.D.F., Yilmaz, F., (2017). Soft power and exchange rate volatility. Int. Finance 20, 271-288. https://doi.org/10.1111/infi.12117

Charvin, V., Fullwood, J., James, J., (2014). The fair value of FX options. Do you get what you pay for? Quant. Finance 14, 15-23. https://doi.org/10.1080/14697688.2013.787493

Costantini, M., Cuaresma, J.C., Hlouskova, J., (2016). Forecasting errors, directional accuracy and profitability of currency trading: The case of EUR/USD exchange rate. J. Forecast. 35, 652-668. https://doi.org/10.1002/for.2398

Crowder, W.J., (2014). Real exchange rate persistence in US dollar PPP systems. Int. Finance 17, 209-240. https://doi.org/10.1111/infi.12048

Doval, E., (2016). Is outsourcing a strategic tool to enhance the competitive advantage? Rev. Gen. Manag. 23, 78-87.

Edens, C., (2010). A holistic view of corporate foreign exchange exposure management. J. Corp. Treas. Manag. 3, 341347.

Engel, C., (2016). Exchange rates, interest rates, and the risk premium. Am. Econ. Rev. 106, 436-474.

Frishberg, M., Gobble, M.M., (2013). Considering exchange rate risk in outsourcing. Res. Technol. Manag. 56, 5-7. https://doi.org/10.5437/08956308X5605001

Galeshchuk, S., Mukherjee, S., (2017). Deep networks for predicting direction of change in foreign exchange rates. Intell. Syst. Account. Finance Manag. 24, 100-110. https://doi.org/10.1002/isaf.1404

Gylling, M., Heikkilä, J., Jussila, K., Saarinen, M., (2015). Making decisions on offshore outsourcing and backshoring: A case study in the bicycle industry. Int. J. Prod. Econ. 162, 92-100. https://doi.org/10.1016/j.ijpe.2015.01.006

Issing, O., (2018). America's dollar power politics. Int. Econ. 32, 46-69.

Jankensgård, H., Hoffmann, K., \& Rahmat, D. (2014). Derivative usage, risk disclosure, and firm value. Journal of Accounting \& Finance (2158-3625), 14(5), 159-174.

Kroes, J.R., Manikas, A.S., (2014). Cash flow management and manufacturing firm financial performance: A longitudinal perspective. Int. J. Prod. Econ. 148, 37-50. https://doi.org/10.1016/j.ijpe.2013.11.008

Kumar, V.R., Joshi, G., (2014). Testing efficient market hypothesis in the foreign exchange market. CLEAR Int. J. Res. Commer. Manag. 5, 4-16.

Ljung, G.M., Ledolter, J., Abraham, B., (2014). George Box's contributions to time series analysis and forecasting. Appl. Stoch. Models Bus. Ind. 30, 25-35. https://doi.org/10.1002/asmb.2016 
Magee, S., (2013). The effect of foreign currency hedging on the probability of financial distress. Account. Finance 53, 1107-1127. https://doi.org/10.1111/j.1467-629X.2012.00489.x

Manzur, M., Hoque, A., Poitras, G., (2010). Currency option pricing and realized volatility. Bank. Finance Rev. 2, 7385.

McMillan, C.J., Overall, J.S., (2017). Crossing the chasm and over the abyss: Perspectives on organizational failure. Acad. Manag. Perspect. 31, 271-287. https://doi.org/10.5465/amp.2017.0018

Mishler, M.D., (2017). Currency turmoil, price, and profit in global markets. J. Account. 223, 1-6.

Moosa, I.A., (2004). Is there a need for hedging exposure to foreign exchange risk? Appl. Financ. Econ. 14, $279-283$. https://doi.org/10.1080/0960310042000201219

Parlapiano, F., Alexeev, V., Dungey, M., (2017). Exchange rate risk exposure and the value of European firms. Eur. J. Finance 23, 111-129. https:// doi.org/10.1080/1351847X.2015.1072570

Pérez-González, F., Yun, H., (2013). Risk management and firm value: Evidence from weather derivatives. J. Finance 68, 2143-2176. https://doi.org/10.1111/jofi.12061

Pilbeam, K., Langeland, K.N., (2015). Forecasting exchange rate volatility: GARCH models versus implied volatility forecasts. Int. Econ. Econ. Policy 12, 127-142. https://doi.org/10.1007/s10368-014-0289-4

Saundage, D., Cybulski, J.L., Dharmasena, L., Keller, S., (2016). Teaching data analysis with interactive visual narratives. J. Inf. Syst. Educ. 27, 233-247.

Spreckelsen, C., Mettenheim, H.-J., Breitner, M.H., (2014). Real-time pricing and hedging of options on currency futures with artificial neural networks. J. Forecast. 33, 419-432. https://doi.org/10.1002/for.2311

Stulz, R., (2013). How companies can use hedging to create shareholder value. J. Appl. Corp. Finance 25, $21-29$. https://doi.org/10.1111/jacf.12038

Treanor, S.D., Rogers, D.A., Carter, D.A., Simkins, B.J., (2014). Exposure, hedging, and value: new evidence from the U.S. airline industry. Int. Rev. Financ. Anal. 34, 200-211. https:// doi.org/10.1016/j.irfa.2014.04.002

VanderLinden, D., (2014). Is hedging foreign currency bids with options desirable? An applied analysis for small firms. J. Appl. Financ. Res. 1, 9-19.

Veestraeten, D., (2013). Currency option pricing in a credible exchange rate target zone. Appl. Financ. Econ. 23, 951962. https://doi.org/10.1080/09603107.2013.778945

Weltman, D., Eakin, M., (2018). Basic guidelines for common business statistics metrics. Bus. Educ. Innov. J. 10, $21-26$.

Witkowska, J., (2017). Implications of the transatlantic trade and investment partnership (TTIP) for investment flows between the European Union and the USA. Comp. Econ. Res. 20, 25-39. https://doi.org/10.1515/cer-2017-0018

Wong, K.P., (2017). Cross-hedging ambiguous exchange rate risk. J. Futur Mark. 37, $132-147$. https://doi.org/10.1002/fut.21793 